\title{
Margaret McCartney: Scottish GP contract-responsibility without power?
}

\author{
Margaret McCartney general practitioner
}

Glasgow

The proposed Scottish GP contract is clearly intended to shore up GPs and support primary care, and there's much in it to like. It effectively underwrites premises so that younger GPs won't be dissuaded from joining a practice that owns its buildings. It includes a minimum income expectation for 40 hour full time GP equivalents, some $20 \%$ of whom in Scotland earn less than the proposed minimum of $£ 80000$.

It contains impressive statements on the link between workforce morale and patient experience and says that not all patients need a doctor's expertise to be treated. And help is promised through pharmacists and physiotherapists stepping in and up, as well as nurses and receptionists being trained to do more. It reads as though GPs, taking on the role of expert medical generalist and team leader, will become quasi-salaried.

The critical issue for me is this: health boards, under the new contract, will be responsible for managing the team to which the GP provides clinical leadership. Some of this may make sense, and district nurses and health visitors in my area have long been employed by the health board. But it's also a recipe for fractured relationships.

It's striking, and impressive, how well some other professionals have laid out what they can do and what resources they need to do it

Morale comes, often, from team support. Make the team a group of temporary, ever moving players, and we lose that sustenance and create administrative mess. A team of regular district nurses whose coffee cups are stored in the tearoom, who know the staff and patients, is a different proposition from a team who can't offer patients continuity of care (and who don't know what the octogenarian down the road likes-or what she's usually like).

Another big issue with the contract is its reliance on advance care planning to reduce admissions despite large uncertainties about whether this is possible. ${ }^{12}$ My fear is that GPs will continue to fill the gaps created around work that others don't take on-and that we may have little choice in what that work is.

It's striking, and impressive, how well some other professionals have laid out what they can do and what resources they need to do it. I don't think that GPs, as a group, have ever articulated this well enough.

I can see two futures. One is where GPs see the most complex patients, filling in workforce gaps where needed and doing lots of paperwork. The second is where we become salaried and clearly define what it is that we do and what resources we need. As it stands, this would inevitably lead to waiting lists for GP appointments.

What about incorporating another way-a rigorous and bottom-up identification and exclusion of the administrative and system waste that GPs don't need to do $?^{34}$ I have little doubt that the will to make a good contract is there. But, as proposed at present, we retain responsibility without necessarily the resources to discharge it.

\section{Competing interests: See www.bmj.com/about-bmj/freelance-} contributors/margaret-mccartney.

Provenance and peer review: Commissioned; not externally peer reviewed.

Follow Margaret on Twitter, @mgtmccartney

1 University of York Centre for Reviews and Dissemination. National Institute for Health Research. Advance care planning — evidence briefing. Nov 2014. https://www.york.ac.uk inst//crd/pdf/Advance\%20care\%20planning.pdf.

2 WeathersEO'CaoimhRCornallyN. Advance care planning: A systematic review of randomised controlled trials conducted with older adults. Maturitas2016;91:101-9. www. sciencedirect.com/science/article/pii/S0378512216301487. doi:10.1016/j.maturitas.2016.06.01627451328

3 McCartneyM. Margaret McCartney: Evidence based protest for the NHS. BMJ2016;354:i4745. doi:10.1136/bmj.i474527585705

4 McCartneyM. Margaret McCartney: Why GPs are stressed. BMJ2016;352:i693. doi:10.1136/bmj. 169326856352

Published by the BMJ Publishing Group Limited. For permission to use (where not already granted under a licence) please go to http://group.bmj.com/group/rights-licensing/ permissions 